\title{
Teaching NeuroImages: Parkinsonism Secondary to a Metastatic Lesion Involving the Substantia Nigra
}

Kosei Hirata, MD, Takanori Yokota, MD, PhD, and Yoshiharu Miura, MD, PhD

Neurology ${ }^{\circledR}$ 2021;96:e1800-e1801. doi:10.1212/WNL.0000000000011162

\section{Figure Brain MRI Findings}
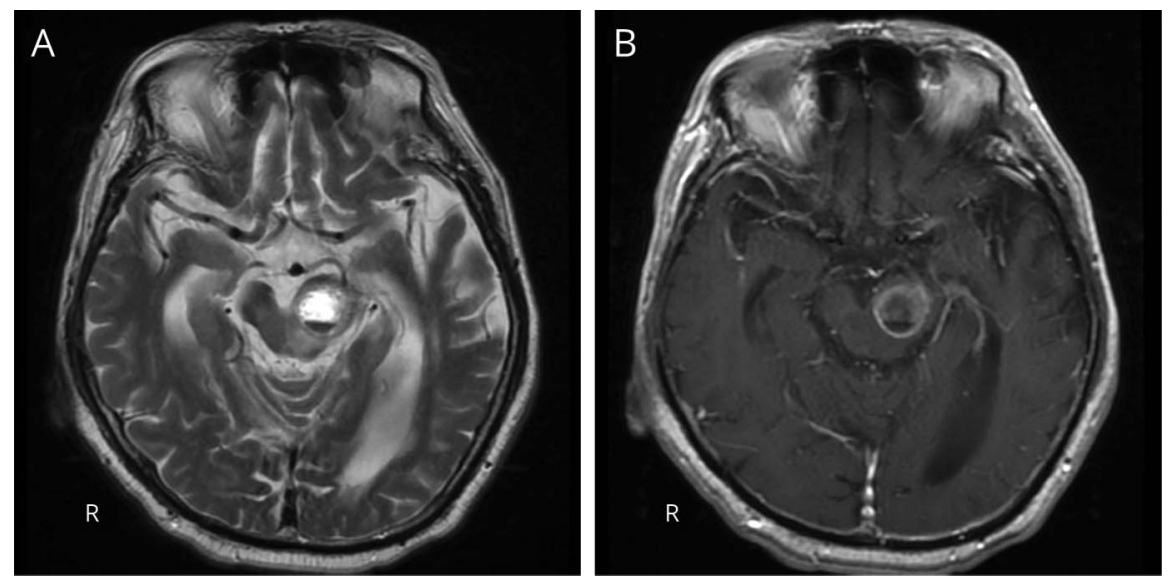

(A) Axial T2-weighted and (B) T1-weighted images with gadolinium contrast show ring enhanced mesencephalic mass involving left substantia nigra.

A 74-year-old man with a 9-month history of treatment for metastatic small cell lung carcinoma presented with 3 months of gradual-onset small steps and stooped posture. His medical history was unremarkable except for pneumothorax in his 30s. Neurologic examination revealed bradykinesia, rigidity in the right extremities, stooped posture, and hyperreflexia in all extremities. Brain MRI showed a ring-enhanced lesion in the midbrain involving the left substantia nigra (figure), which was not evident on MRI 4 months earlier. Although he underwent whole-brain irradiation with a marked decrease in the lesion size, his parkinsonism did not remit. He was unresponsive to levodopa up to $300 \mathrm{mg} / \mathrm{d}$. His parkinsonism did not worsen, and he died 4 months after diagnosis.

Although brain tumors at various locations are associated with parkinsonism, metastatic tumors contacting the substantia nigra comprise a rare but important cause of secondary parkinsonism. ${ }^{1,2}$

\section{Study Funding}

No targeted funding reported.

\section{Disclosure}

The authors report no disclosures relevant to the manuscript. Go to Neurology.org/N for full disclosures.

\section{Correspondence}

Dr. Hirata

k-hirata.nuro@tmd.ac.jp

\section{MORE ONLINE}

$\rightarrow$ Teaching slides

links.lww.com/WNL/ B267

From the Department of Neurology (K.H., Y.M.), Tokyo Metropolitan Cancer and Infectious Diseases Center, Komagome Hospital; and Department of Neurology and Neurological Science (K.H., T.Y.), Graduate School of Medical and Dental Sciences, Tokyo Medical and Dental University, Japan.

Go to Neurology.org/N for full disclosures. 


\begin{tabular}{lll}
\hline Appendix & Authors & \\
\hline Name & Location & Contribution \\
\hline $\begin{array}{l}\text { Kosei } \\
\text { Hirata, MD }\end{array}$ & $\begin{array}{l}\text { Tokyo Metropolitan Cancer } \\
\text { and Infectious Diseases } \\
\text { Center, Komagome } \\
\text { Hospital, Japan }\end{array}$ & $\begin{array}{l}\text { Drafted the manuscript for } \\
\text { intellectual content, primary } \\
\text { clinical care of the patient }\end{array}$ \\
\hline $\begin{array}{l}\text { Takanori } \\
\text { Yokota, } \\
\text { MD, PhD }\end{array}$ & $\begin{array}{l}\text { Tokyo Medical and Dental } \\
\text { University, Japan }\end{array}$ & $\begin{array}{l}\text { Revised the manuscript for } \\
\text { intellectual content }\end{array}$ \\
\hline $\begin{array}{l}\text { Yoshiharu } \\
\text { Miura, } \\
\text { MD, PhD }\end{array}$ & $\begin{array}{l}\text { Tokyo Metropolitan Cancer } \\
\text { and Infectious Diseases } \\
\text { Center, Komagome }\end{array}$ & $\begin{array}{l}\text { Revised the manuscript for } \\
\text { intellectual content }\end{array}$ \\
\hline
\end{tabular}

\section{References}

1. Yasuhara T, Agari T, Kambara H, et al. Parkinsonism related to brain tumors: a case

Drafted the manuscript for intellectual content, primary Center, Komagome clinical care of the patient

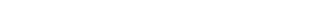 report and review of the literature. Open Neurosurg J 2009;2:4-7.
2. Joutsa J, Horn A, Hsu J, Fox MD. Localizing parkinsonism based on focal brain lesions. Brain 2018;141:2445-2456. (1) 


\section{Neurology}

Teaching NeuroImages: Parkinsonism Secondary to a Metastatic Lesion Involving the
Substantia Nigra

Kosei Hirata, Takanori Yokota and Yoshiharu Miura

Neurology 2021;96;e1800-e1801 Published Online before print November 9, 2020

DOI 10.1212/WNL.0000000000011162

This information is current as of November 9,2020

\section{Updated Information \&} Services

References

Subspecialty Collections

\section{Permissions \& Licensing}

Reprints including high resolution figures, can be found at: http://n.neurology.org/content/96/13/e1800.full

This article cites 2 articles, 0 of which you can access for free at: http://n.neurology.org/content/96/13/e1800.full\#ref-list-1

This article, along with others on similar topics, appears in the following collection(s):

All Clinical Neurology

http://n.neurology.org/cgi/collection/all_clinical_neurology

Gait disorders/ataxia

http://n.neurology.org/cgi/collection/gait_disorders_ataxia

Metastatic tumor

http://n.neurology.org/cgi/collection/metastatic_tumor

MRI

http://n.neurology.org/cgi/collection/mri

Parkinson's disease/Parkinsonism

http://n.neurology.org/cgi/collection/parkinsons_disease_parkinsonism

Information about reproducing this article in parts (figures,tables) or in its entirety can be found online at:

http://www.neurology.org/about/about_the_journal\#permissions

Information about ordering reprints can be found online:

http://n.neurology.org/subscribers/advertise

Neurology ${ }^{\circledR}$ is the official journal of the American Academy of Neurology. Published continuously since 1951, it is now a weekly with 48 issues per year. Copyright (C 2020 American Academy of Neurology. All rights reserved. Print ISSN: 0028-3878. Online ISSN: 1526-632X.

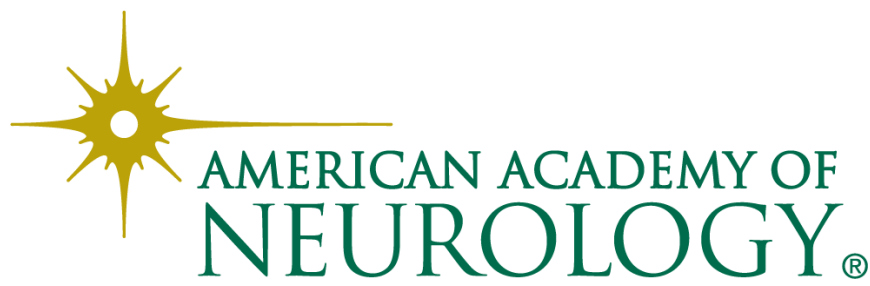

